\title{
From Documentary to Fiction and Back: Reality and Contingency in Wang Bing's and Jia Zhangke's films
}

\section{Sebastian Veg}

\section{(2) OpenEdition}

\section{Journals}

Édition électronique

URL : http://journals.openedition.org/chinaperspectives/2223

DOI : 10.4000/chinaperspectives.2223

ISSN : 1996-4617

Éditeur

Centre d'étude français sur la Chine contemporaine

\section{Édition imprimée}

Date de publication : 15 septembre 2007

ISSN : 2070-3449

\section{Référence électronique}

Sebastian Veg, «From Documentary to Fiction and Back: Reality and Contingency in Wang Bing's and Jia Zhangke's films », China Perspectives [En ligne], 2007/3 | 2007, mis en ligne le 09 avril 2008, consulté le 28 octobre 2019. URL : http://journals.openedition.org/chinaperspectives/2223 ; DOI : 10.4000/chinaperspectives.2223 
U

\title{
From Documentary to Fiction
}

\section{and Back:}

\author{
Reality and Contingency in Wang Bing's and sia Zhangke's films (1)
}

SEBASTIAN VEG

The generation of "independent" Chinese directors has repeatedly crossed and displaced the borders between fiction and documentary film in their works. While originally linked to practical constraints, this trend has developed into a full-fledged aesthetic programme in the works of Wang Bing and Jia Zhangke. Both directors document the demise of the world of China's state-owned industries and its impact in terms of livelihoods and social ideals, highlighting the subjective dimension of its dystopic significance. Finally, this article argues that both directors seek to define an aesthetics of contingency, commensurate both with the historical processes they document, and the absurdity felt by individuals who have no control over them.

$\mathrm{J}$ ean-Luc Godard famously remarked that "All great fiction films tend toward documentary, just as all great documentaries tend toward fiction [...] whoever entirely opts for one necessarily finds the other at the end of the road." While the artistic basis for such a parallel has sometimes proven elusive, recent films from China show a remarkable convergence between the genres, in terms of both techniques, topics and directors. If Jia Zhangke's documentary In Public (2001), shot largely in the Datong railway station, appeared as a director's scrapbook somehow appended to the corresponding fiction Unknown Pleasures, his latest feature film Still Life (2006) is on the contrary presented as an "outgrowth" of the documentary Dong that Jia originally set out to shoot. More importantly, Jia is not the only major director to be switching genres: Ning Ying's 2002 documentary The Road of Hope met with an international success comparable to her feature films; Li Yang obtained the Silver Bear in Berlin in 2003 for his first feature, Blind Shaft (adapted from a story by Liu Qingbang), after directing three documentaries. His latest film Blind Mountain (2007) is a feature film about the trafficking of women, based on documentary research and a large number of interviews with women kidnapped and sold into marriage.

Historically, the rise of "independent" Chinese cinema in the 1990s is inextricably linked with the documentary genre. At a time when censorship of officially approved films was still pervasive, the emergence of independent documentary in the early 1990s reflected a new generation of directors choosing to begin working entirely outside the state-controlled production and dis- tribution system. Documentary films were not only cheaper, as Li Yifan forcefully underlined during a panel discussion, they also did not fall within the direct responsibility of the state administration for radio, film and television. It was therefore an obvious way for young directors to experiment with new themes and techniques, without financial support, but also without any direct interference from the propaganda organs. Historically, it therefore comes as no surprise that independent Chinese film grew out of the documentary movement. This is mirrored in the themes favoured by this generation, such as the railroad motive, a classic topic in propaganda film, subverted in Du Haibin's documentary Along the Railway (2001) before returning in In Public, The Road of Hope and Wang Bing's Tiexi qu (2002). In the same way, the mine motive was used by Li Yang and Jia Zhangke in Platform, but also in documentaries such as Xiaopeng's Mine no. 8 (2003). This theme resonates more broadly with Wang Bing's story of the dismantling of the gigantic state-owned enterprises of the north-east in the 1990s, also fictionalised by Wang Chao in The Orphan of Anyang (2001). What started out as a strategy to avoid official interference and the constraints resulting from a lack of funding, therefore developed into a movement with its own dynamic. In the wake of the

1. This article and the preceding one were first given as papers at the conference "Crossing boundaries: Fiction and Documentary in contemporary Chinese cinema" coorganised by the CEFC and the Hong Kong International Film Festival in April 2007. It benefited from discussions with invited directors Jia Zhangke, Wang Bing and Li Yifan and invited speakers Leung Ping-kwan and Jean-Michel Frodon. The author would like to extend special thanks to Li Cheuk-to. 
demise of the aesthetics of (socialist) realism (xianshi zhuyi), directors began to seek a more complex aesthetics of "reality" (xieshi). Their deconstruction of the barrier between subjectivity and objectivity represented a way of calling into question a one-dimensional approach to the relation between cinema and reality. This does not mean that documentary is necessarily more "realistic" than fiction, as Jia Zhangke remarked in an interview: "It is easier to show certain realities in fiction, and they appear more authentic. [...] When you make a documentary, and you want to raise certain questions, people do not necessarily want to talk about their private lives. There's a danger of filming only appearances. It's even more difficult when filming ordinary people, and they are the ones I want to talk about." ${ }^{(2)}$ Furthermore, each genre creates a distinct relationship with the public and private spaces in which they are shown and discussed, with documentary paradoxically appearing as a more "private" form of expression than fiction, at least as far as its audience is concerned. Finally, if documentary is to feature what the essay is to fiction, one may well wonder if the "sixth" generation's navigation between the genres is not also the reflection of the continued importance of sanwen in Chinese writing, and its blurred frontier with fiction.

One may well hesitate: should this interplay of the genres be considered in a historical perspective, within China's unique present socio-political situation, or as a universal aesthetic phenomenon? In a historical light, while the aesthetics of blending fiction with "documents" is characteristic of the generation of "independent" Chinese cinema of the 1990s, their place within the evolution of Chinese film is complex, in that they combine a clear rebuttal of the ideology of socialist realism with a return to themes that seem to spring directly from the canon of leftist cinema: industrial landscapes, railways and train stations, urban modernisation. In this they are closer to realist paeans of a bygone era than to the epic dramas of the 1980s. Their move away from ideology does not exclude a marked preference for filming "ordinary people" and a social dimension rife with political overtones. It is therefore probably not helpful to oppose the uniqueness of China's present transformation and an aesthetic style formulated in more universal terms. In other words, the interplay between documented reality and fictional emplotment is certainly in some way linked with the accelerating destruction, in the 1990s, of the oppressive but familiar world of industry and socialist economy and lifestyle. But at the same time, the new aesthetics is not intent on nostalgically documenting this disappearing world, which remains bound up with ambiguous feelings. It is important to underline that the interplay goes both ways: while the social transformations of contemporary China enter fiction by way of documentary technique or montage, fic- tion also enters documentary through the dramatisation of lives seen in a radically more individual and subjective light than previously. More generally, therefore, it may be argued that the contemporary dynamics serve as a thematic pretext in the quest for a more satisfying aesthetics that is neither directly ideological nor concerned with the issue of reinventing and restaging the nation as in the 1980s.

In this way, the blurring of the boundary between fiction and documentary can be understood in more universal terms, as a continued experiment in defining an aesthetics that engages with reality without being subjected to it, that engages with society without being subordinated to ideology. Of course, this experiment has crucial implications in the present context: Chinese cinema exists within an uncertain public space, bound by implicit or explicit limitations of what it may represent. But, more importantly, this is not a new question. One may recall that the necessity of somehow "incorporating reality" into cinema was raised as early as the 1920s by the Russian and Soviet avant-garde, who coined the distinction between "acted" and "non-acted" cinema. Indeed, the trend spread to literature, with a renewed interest in using "montage" techniques to blend socalled "factography" with fictional narratives. Chinese cinema from the 1930s to now has long been engaged in this debate. Without detaching them from their immediate context, I therefore propose to look at the experiments in contemporary Chinese film against this broader historical backdrop of an aesthetic quest, focusing on two directors whose works are not always considered related, Jia Zhangke and Wang Bing. The link between Jia Zhangke's documentary Public Space and feature Unknown Pleasures yields an example of how similar material can move between fiction and non-fiction. The way in which the third part of Wang Bing's documentary Tiexi qu, entitled "Yanfen jie" (Makeup street) relates to the other parts serves as an example of the subversion of documentary models that call into question boundaries between subjectivity and objectivity. This tension arguably both constructs and continually challenges the aesthetics that, I believe, are in the process of emerging from this collective experiment.

\section{An historic moment: documenting the end of the industrial world}

The films that embody the new aesthetics of the 1990s are undoubtedly linked to the great economic and social transforma-

2. Interview with Jia Zhangke, China Perspectives, $n^{\circ} 60$ (July-August 2005), p. 47. 
Inhabited spaces: changing rooms in a factory and the sanatorium where the workers undergo medical checkups in Wang Bing's West of Tracks immediate connection with the world of industry, mining, and the railway network, some of the pillars of socialist China. These places are, to an extent, able to tell their own story, as they come to life with characters. The waiting man in the first scene, the boy with toothache on the bus, the woman who misses the bus at the mine, and finally the man with the dark glasses observing people's movements at the long-distance bus station all weave in and out of the director's field of vision. Although they never speak to the camera, and cannot be heard distinctly, they convey, simply by their expressions and gestures, a deep sense of what Jia calls "the melancholy and despair of drifting among the dust." (5)

In the same way, while Wang Bing asserts the importance of the factories themselves, these spaces come to life through the workers that inhabit them: in "Gongchang," the actual production occupies only a small part of the film, while the workers are mainly seen playing cards, mahjong, celebrating the $\mathrm{New}$ Year, watching television, and taking endless and repeated showers in steamy industrial shower rooms. In this sense, the film shows how production spaces and living spaces are inextricably linked, and if the film is indeed the story of the factories, this story is told through the people in them. A sense of impending doom is effectively imparted in the first part in the many scenes in which the workers are simply sitting around and waiting. These scenes foreshadow the closing of the entire complex, which in one case is captured live, as a young worker lounges on a bench, only to be interrupted by a colleague bursting in to announce the closing of the zinc mills. In this way the film shows how the closing of the industrial complex is bound up with individual lives and effectively creates a sense of doom.

Wang Bing, perhaps more explicitly than Jia Zhangke, films the end of the Chinese collective industrial system, paying close attention to the physical dismantling and breaking down of architectural structures. In "Gongchang I", the camera dwells at length on the steel plate works, a factory that has already been closed for several years. The empty broken windows are shown first from the outside, then again from the inside, with light streaming through to illuminate the whole vast volume of the main workshop. The camera wanders continuously for six minutes, exploring corner after corner of the workshop without finding a trace of human presence. This episode, which serves only as foreshadowing in part I, is echoed by many more in part II, in which the factories seem to be literally breaking apart. In one of the opening scenes, there is a leak in the steel mill from which liquid metal spills out. In a later scene, the entire piping system of the factory has frozen and burst after being abandoned during the winter. The workers return to their familiar surroundings

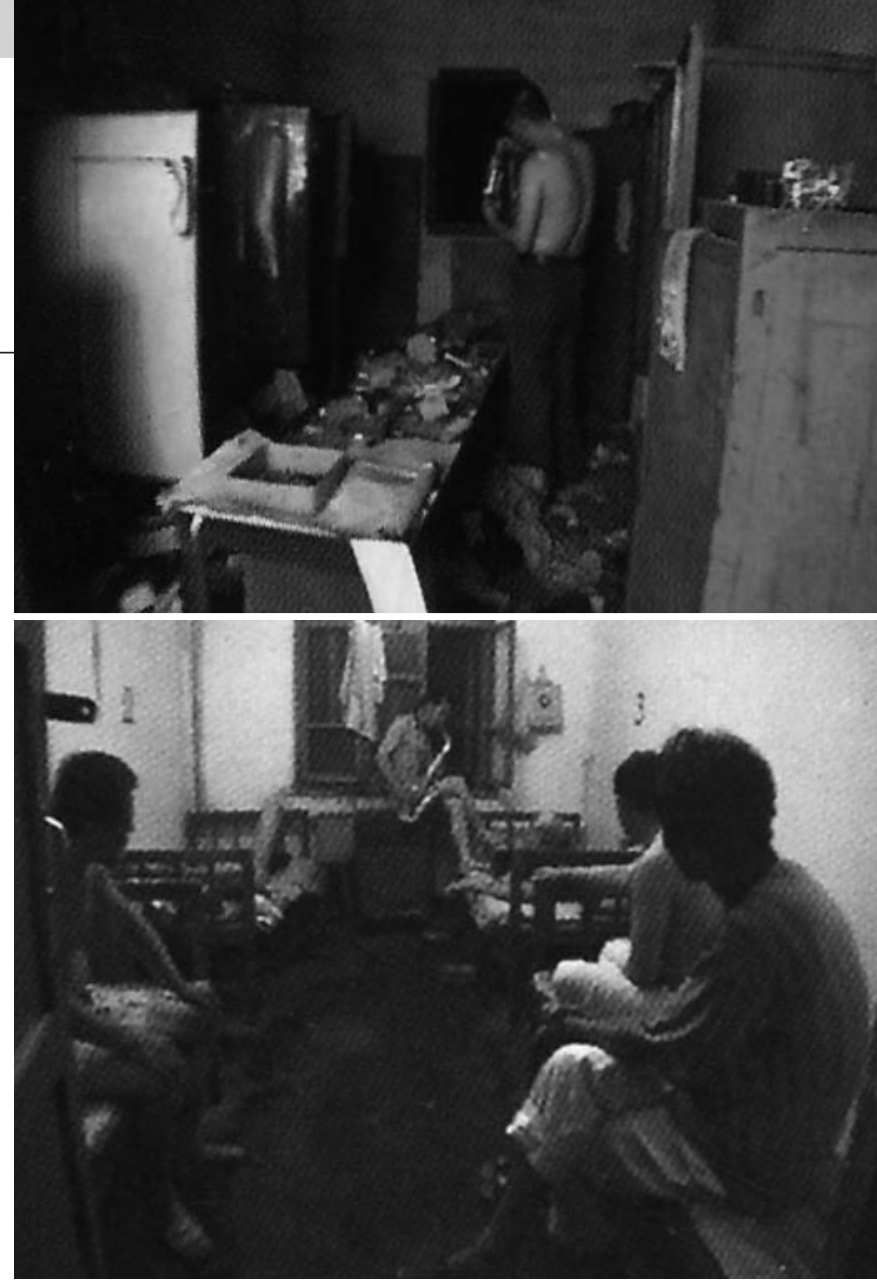

only to find them invaded by ice. Finally, the film ends with the demolition of the steel sheet works, completing the symmetry between the two parts-the initiation into this parallel world of industrial alchemy, followed by its imminent destruction. The workers themselves participate in the destruction, in a striking image of the ambiguity it is imbued with. Therefore, in Wang Bing's as in Jia Zhangke's film, I would argue that the filming of the physical spaces of the socialist lifestyle, and their degradation or dismantling, is a way to open a new aesthetic approach, a form of realism that imbues these classical spaces of socialist realism with a new subjectivity, which can be viewed as either a personification of the spaces themselves through human presence, or the breaking down of the collective space into the individual lives that inhabit it.

\section{From objectivity to subjectivity: the end of ideals?}

Of course, the dismantling of a Chinese factory is always about much more than architecture and even economics. Although Wang Bing's interest in the dismantling of these monumental structures is perhaps aesthetically more radical even than Jia Zhangke's vision of the dismantling of Fengjie in Still Life, his story of the end of Chinese industry is also a strongly subjective one. In this light, Lü Xinyu's conclusion that documentary in China is linked to the ruins of a utopian ideal, should not be

5. Jia Zhangke, "Gonggong changsuo. Daoyan de hua", ibid., p. 3 


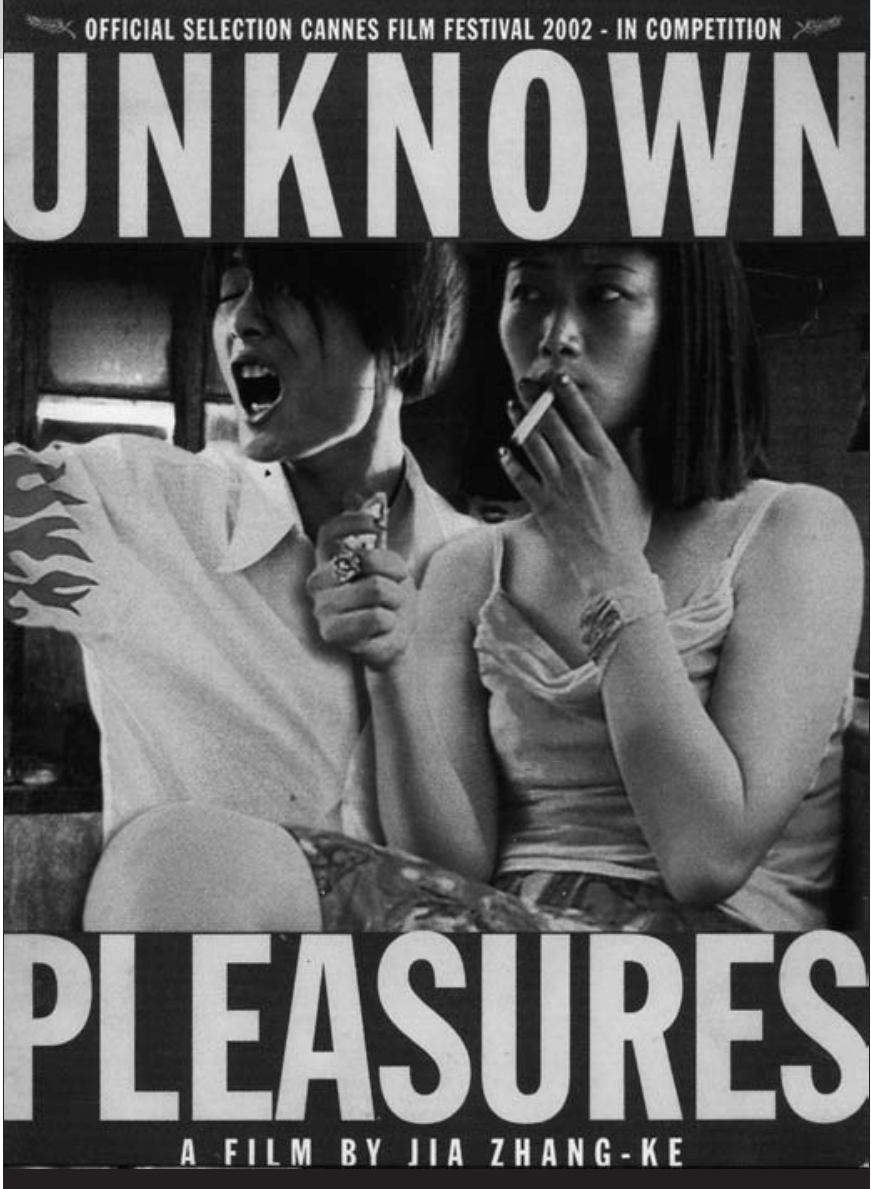

the film, Makeup Street (Yanfen jie), which I propose to analyse in parallel with Jia's film Unknown pleasures, in which the presence of Binbin's neighbourhood committee chief also serves as a reminder of the less pleasant aspects of collective existence.

An innocent spectator, not knowing about its status and without the subtitles providing factual information, could probably watch Yanfen $\ddot{\text { jie }}$ and believe it is a feature film. Ostensibly, this threehour long third part of Wang Bing's work is about the destruction of the workers' living quarters in Tiexi in 2001. But it is also a strongly dramatised story, with recurring characters, who have been clearly individualised in the editing, bringing out psychology, family situation, and various events. The film thus focuses on a group of young people who regularly meet in Mr Chi's Hongxiang shop, mainly Zhao Bo (Bobo), who drives a taxi, his friend Whitey, Ren Huan, Wang Zhen. A long episode at the beginning revolves around a Valentine's day project, in which Bobo enrols Chen Ying, convincing her to go to Zhang Na's house to give her flowers on his behalf. They later all congregate at Bobo's house, after Whitey has been stood up by his girlfriend, and fool around making jokes. This group of Fellinian vitelloni are mainly interested not in the closing industries, nor even in the destruction of the neighbourhood in which they live, but in pop music (liuxing yinyue) and love stories. Their hopes revolve around making a little money, and finding the girlfriend of their dreams (the perspective is decidedly male). Later in the film, Bobo and Whitey have a discussion in Bobo's house, in which the latter talks about the advantages of driving a taxi. When Bobo asks Whitey why he seems to lack any ideal or dream, Whitey answers that ideals do not feed anyone, in a dialogue that might just as well have been scripted for a feature. The following shot is of Whitey on his bed singing "Ai ni wan nian" (I'll love you for ten thousand years). This mixture of hope

and despair, of the dreams brought to small towns by popular music, is exactly what Jia Zhangke has become famous for dramatising in his feature films.

Unknown Pleasures is entitled in Chinese "Ren xiao yao" (Free of all cares), after the song by the Taiwanese singer Ren Xianqi that punctuates the film and lends words to the contradictory aspirations of Binbin and Xiao Ji. This can be seen in a further development of the discovery of Teresa Teng songs on the radio by the children of Fenyang in Platform, which Jia has often mentioned in interviews as the outstanding event of the 1980s in his eyes. This song is first sung by the local beauty Qiaogiao, who Xiao Ji falls in love with, during her dance show to promote Menggu wangjiu liquor. Binbin sings it at the karaoke with his girlfriend, admiring the Monkey King's freedom on television, and again in the police station after being arrested. It is thereby related, both by the meaning of its lyrics, and by its role in the structure of the film, to the aspiration of the "floating" post-adolescents to be "free of all cares," free to fall in love, to make money, and to escape from Datong. As Jia Zhangke writes in the summary of the scenario: " 'Free of all cares' is an old saying. For Qiaogiao it means: 'Do whatever you feel like doing." (7) An effective image of the difficulty of making these aspirations come true appears in the endless scene in which Xiao Ji gets stuck with his motorcycle in the dried-up river bed in the middle of Datong. This comment on the industrial wasteland in which the character's dreams literally get bogged down is certainly one of the most effective and perhaps unbearable moments of the film. The last line of the song "I roam the world

6. Lü Xinyu, Jilu Zhongguo: dangdai Zhongguo xin jilu yundong. (Recording China: The Contemporary New Documentary Movement in China), Beijing, Sanlian, 2003. 
From Documentary to Fiction and Back

Zhao Weiwei (Binbin) and Zhou Qingfeng (Yuanyuan) in a train-station turned restaurant in Unknown Pleasures

Zhao Tao as Qiaoqiao, walking in the dried-up river bed in Datong in Unknown Pleasures

with the wind, free of all cares" is a comment on the end of the film, in which Binbin is charged with the bank robbery at the police station, while Xiao Ji, abandoning his motorcycle, takes to the road alone, leaving Datong and his imprisoned friend behind. ${ }^{(8)}$

As a film about hope, despair and the way in which aspirations to freedom translate into indifference to others, Unknown pleasures certainly owes a debt to In Public, in which the dried-up river bed first appeared. The images of a man endlessly waiting at a remote suburban train station for a woman (Jia Zhangke adds in the script: "we don't know what connection there is between them"), of ordinary people waiting at a bus station in the mine area, of the mafia type with dark glasses watching the women go by, and finally of the long-distance bus station from which people leave Datong, all set the stage for and shape the contradictory feelings of the heroes' "melancholy and despair of drifting among the dust" in Unknown pleasures. The use of the long-distance bus station in which In Public ends, with Binbin's mother checking bus tickets, as the setting for the opening scene of Unknown Pleasures, and again for the scene in which Binbin and his girlfriend break up (sitting on benches that seem to have been taken out of an old hard-seater carriage), is an example of the spatial continuity between fiction and documentary. Similarly, the dried-up river bed in the middle of Datong that effectively sums up the difficulties of escaping from the declining industrial wasteland of Shanxi, shows how fiction is imbued with the spirit of place, how it literally grows out of places. Jia Zhangke's insistence in an interview that the documentary In Public gave him new creative vitality, "unclotting his blood vessels" (9) is revealing for a method by which fiction emerges from reality. Rather than a comment on the times, I would argue that this intermingling represents a quest for a new aesthetics of reality: in classical avant-garde fashion, as recommended by the LEF (Left Arts Front) artists in the Soviet Union as early as the 1920s, the fictional story develops from the observance of reality, while the nature of the observed reality determines the form of the story. ${ }^{(10)}$

A similar argument can be made for Wang Bing's Yanfen jie. In workers' houses just like to the one in which Binbin's mother lives in Datong, the steel workers of Shenyang go through the same lay-offs (xiagang), possibly with less compensation than she receives. But here also, the focus is on individuals' contradictions, as expressed forcefully twice in the film, when the characters speak about their dreams. In the opening scene, a huge lottery is staged prior to the New Year, and a laid-off worker from Tiexi, Ma Xueping, wins a car. While the gaudy setting recalls the scene in which Qiaoqiao sings to advertise Mongolian alcohol, the worker's reaction runs something like this: "Are you

7. Jia Zhangke, "Ren xiao yao", op. cit., p. 12

8. I have developed this idea in "Karaoké et politique. Plaisirs inconnus de Jia Zhangke", Vacarme, $\mathrm{n}^{\circ} 22$ (Winter 2003), pp. 77-79.

9. Jia Zhangke, "Qu yige chuanshuo zhong de chengshi", art. cit.

10. See for example Shklovski's position in the debate on Dziga Vertov's film and "nonacted" cinema.

11. One could also argue that this shift to a purely individual approach of themes imbued with a heavy collectivist legacy is also used in the fourth part of Wang Bing's film, "Tielu", and Ning Ying's documentary Xiwang zhi lu. Here also, the train system is not used to document reality, but to reflect on people's hopes and ideals, showing individuals, rather than the collective, in a form of subversion, both political and aesthetic, of the realist canon. 
Jia Zhangke standing in the "hole in the wall" during the shooting of Still Life

A woman suddenly surges into the picture in In Public umentary are all there: the asymmetry between the Chinese and English titles of the film, "The good people of the Three Gorges" and "Still Life" points out the interplay between people and places, incorporating the disappearance of Fengjie into a larger scheme of hopes and aspirations. ${ }^{(14)}$

The destruction and construction recorded in the film stand more generally for the randomness of historical processes. What is being destroyed (and possibly rebuilt) is not only architecture, but a complex net of human relations and north-south migrations, between Sanming and his long-lost (but originally kidnapped and trafficked) wife, and between Shen Hong and her husband Guo Bin, a former factory worker turned local big-shot. Chow Yun-Fat imitator "Brother Mark," falls victim to these changes, and is found dead, symbolically buried under the rubble of the construction site in which Sanming works. The farewell scene between Sanming and his wife is set against a contrast that highlights this two-tiered construction: the "hole in the wall" the couple stands in neatly frames a painting-like view of the majestic landscape of the Three Gorges, set to disappear just like the houses of the inhabitants, in a striking image of how individual lives are caught up or "framed," for the space of one moment, within the larger processes of construction and destruction making up history. Jia's emphasis is arguably on fragmentation and contingency, as shown by the non-linear structure of the film in four parts titled Cigarettes, Wine, Tea and Candy. Of course, the overwhelming historic meaning of the Three Gorges in Chinese history and literature (recalled by the allusion to the painting of Kuimen on Chinese bills, and also Dongming's job as an archaeologist (played by Wang Hongwei) digging out the last vestiges of the Han dynasty before the whole area is flooded, deepens the significance of the destruction associated with the dam. Nonetheless, while Wang Hui sees the "new documentary" style of Still Life as an adaptation of epic narrative to China's present environment, ${ }^{(5)}$ I would argue that although it has epic dimensions, the depicted historical process never achieves epic significance. The film's stories of random separation and successful or failed reunion echo the random destruction and reconstruction that make up history. In this respect, the unexpected night-time take-off of the strangely-shaped monument to the displaced inhabitants of Fengjie, while mischievously poking fun at the absurd nature of the monumental development projects initiated by the government (in an epilogue to the cadre-inspection scene in which the bridge suddenly lights up in red), is also a metaphor of the illumination of a fictional moment within reality, which Jia Zhangke uses as a trope for cinema itself. One might say, to paraphrase Cao Xueqin, "when Jia creates reality, reality turns into fiction."

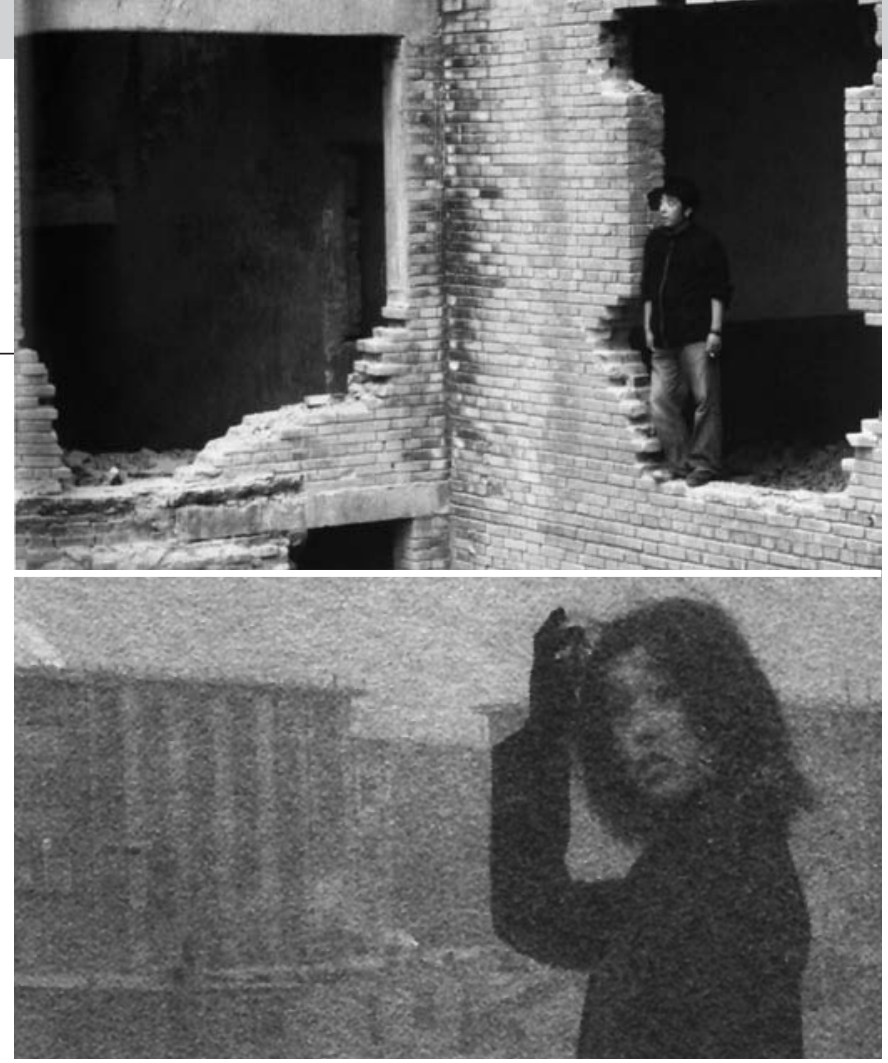

Ultimately, by both recording reality and illuminating it in fictional moments, the interplay between fiction and documentary in recent Chinese cinema highlights the feeling of absurdity of individuals confronted with historical processes they have no control over. Wang Bing and Jia Zhangke demonstrate how fiction is rooted in and at the same time grows out of and outgrows reality, using the spaces of declining socialism to define a feeling of historical uselessness and absurdity which Jia calls "the melancholy and despair of drifting among the dust." Moving beyond the boundaries of subjectivity and objectivity, these films attempt to convey a sense of the contingency of both reality and the cinematic gesture which captures it. In this way they define a new aesthetics, liberated from the sense of historical destination and the ideological code of socialist realism, but equally reluctant to erect the completeness of a utopian fictional narrative as an alternative to reality.

14. Li Yifan and Yan Yu's documentary also works in much the same way to construct individual stories, including revolutionary history with a reminder of the Korean war, against the overall landscape of destruction.

15. Wang Hui "Yong jishi shishi de fangshi zhanxian suipianhua de shidai" (Using a documentary epic style to show a fragmentary era), in Zhongguo duli dianying, op. cit., p. 264. 